\title{
Comparison between immunofluorescence and immunohistochemistry for Listeria monocytogenes detection in formalin-fixed paraffin-embedded tissues
}

\author{
Kelen Regina Ascoli Baldi ${ }^{1,2}$ (i) Jéssica Line Farias de Lima $^{3}$ (D) Isabela Gimenes da Silva ${ }^{2}$ (D) \\ Fernanda Felicetti Perosa ${ }^{2}$ (i) Ricardo Evandro Mendes ${ }^{1,2}$ (i) Teane Milagres Augusto Gomes ${ }^{1,2^{*}}$ (i)
}

${ }^{1}$ Pós-graduação em Produção e Sanidade Animal, Instituto Federal Catarinense (IFC), Concórdia, SC, Brasil.

${ }^{2}$ Centro de Diagnóstico e Pesquisa em Patologia Veterinária, Instituto Federal Catarinense (IFC), 89703-720, Concórdia, SC, Brasil. E-mail: teane.gomes@ifc.edu.br. "Corresponding author.

${ }^{3}$ Departamento de Patologia Animal, Universidade Federal de Pelotas (UFPel), Pelotas, RS, Brasil.

ABSTRACT: Listeria monocytogenes is a bacterium that infect humans and animals and causes a zoonotic disease characterized by encephalitis, septicemia or abortion. In addition, listeriosis leads to significant economic losses due to animal death and sacrifice. This research compared the technique of immunofluorescence (IF) and immunohistochemistry (IHC) for the diagnosis of L. monocytogenes in formalin-fixed and paraffin-embedded (FFPE) tissues. A total of 30 tissue blocks from 15 animals with history and/or lesions compatible with listeriosis were selected. For both IHC and IF, the same diluted (1:200) polyclonal primary antibody was used against L. monocytogenes serotypes 1 and 4. For IHC, a polymer secondary antibody conjugated to peroxidase (HRP) was used. For IF, samples were incubated with a fluorescein-labeled anti-rabbit IgG secondary antibody. Each sample was classified according to the presence and percentage of immunolabeling area. From 30 samples, 10 were positive at least for one technique, whereas eight samples were positive for both IHC and IF with similar score. There was strong immunolabeling in tissue samples from bovines experimentally infected with L. monocytogenes ATCC 7644, as well as in nervous tissues from naturally infected ruminants. Additionally, IF did not show any difference in sensitivity when compared to IHC. Using processed biological materials for IF, instead of fresh tissues, is a quite unique technique, since there are few protocols described. Therefore, this study demonstrated that both techniques are efficient to detect L. monocytogenes in FFPE tissues.

Key words: listeriosis, immunological techniques, veterinary diagnostics.

Comparação entre imunofluorescência e imuno-histoquímica para deteç̧ão de Listeria monocytogenes em tecidos fixados e parafinizados

RESUMO: Listeria monocytogenes é uma bactéria que infecta humanos e animais, podendo causar uma doença zoonótica caracterizada por encefalite, septicemia e abortos. Além disso, a listeriose resulta em perdas econômicas significativas pela morte e sacrificio de animais. $O$ objetivo deste trabalho foi comparar a técnica de imunofluorescência (IF) e imuno-histoquímica (IHQ) para detecção de L. monocytogenes em tecidos fixados e parafinizados. Foram selecionados 30 blocos de tecidos de 15 animais com histórico elou lesóes compativeis com listeriose. Para ambas as técnicas, foi utilizado o mesmo anticorpo primário policlonal diluído (1:200) para detecção de L. monocytogenes sorotipos 1 e 4. Para a IHQ foi utilizado anticorpo secundário em polímero acoplado a peroxidase (HRP). Para a IF, as amostras foram incubadas com anticorpo secundário anti-IgG de coelho marcado com fluoresceína. Cada amostra foi classificada quanto à presença de imunomarcação e porcentagem de área positiva. Das 30 amostras, 10 foram positivas em pelo menos uma das técnicas, sendo oito amostras positivas em ambas IHQ e IF com o mesmo escore. Houve forte imunomarcação tanto em amostras de bovino experimentalmente infectado com L. monocytogenes ATCC 7644, como em amostras de tecido nervoso de ruminantes naturalmente infectados. Além disso, a IF não apresentou diferença na sensibilidade quando comparada com a IHQ. O uso de materiais biológicos processados para IF, ao invés de tecidos frescos, é algo inovador, uma vez que existem poucos protocolos descritos. Portanto, este estudo demonstrou que as duas técnicas foram eficientes para detectar L. monocytogenes em tecidos fixados em formol e parafinizados.

Palavras-chave: listeriose, técnicas imunológicas, diagnóstico veterinário.

\section{INTRODUCTION}

Listeriosis is one of the main foodborne diseases that cause systemic infection in several animal species and in humans, resulting in a high lethality rate in infected patients (SWAMINATHAN \& GERNER-
SMIDT, 2007). The disease is often caused by Listeria monocytogenes, a flagellate, Gram positive and intracellular facultative bacterium (LIU, 2013), which leads to three distinct clinical manifestations: sepsis, with multiple abscesses in the spleen and liver; reproductive, with abortion; and neurological, 
characterized by rhombencephalitis and microabscesses (LOPES, 2010; OEVERMANN et al., 2010).

In domestic animals, listeriosis mainly affects sheep, goats, and bovines. Encephalitis is the most common clinical sign of listeriosis in ruminants; although, other manifestations of the disease are also described in these animals (LOW \& DONACHIE, 1997). The diagnosis of listeriosis in veterinary medicine is mainly based on the histopathological description associated with clinical signs; however, diagnostic confirmation by immunohistochemistry (IHC) technique, Gram staining and/or bacteriological culture is crucial (JOHNSON et al., 1995; LOEB, 2004). Molecular techniques such as PCR are also used for definitive diagnosis (KIRINUS et al., 2010; BARKALLAH et al., 2016). Currently, there are few studies describing the application of immunofluorescence (IF) for Listeria spp. in previously fixed and processed tissues (HENKE et al., 2015); however, its applicability for pathogen detection in a laboratory routine is unknown. This highlighted the importance of providing other reliable techniques for in situ confirmation of listeriosis in field-collected samples.

The optimization and use of immunological techniques, such as IHC (JOHNSON et al., 1995; ROCHA et al., 2017) and IF (HENKE et al., 2015) in formalin-fixed paraffin-embedded (FFPE) tissues enabled the diagnosis of Listeria sp. without the need of biosafety laboratory infrastructure for bacterial isolation and DNA extraction from fresh tissues. In addition, these techniques also allowed retrospective studies using archived materials.

For fresh samples, definitive diagnosis of listerioris based on microbiological isolation of the agent is relatively time-consuming and limited (JOHNSON et al., 1995). Thus, the verification of other accessible, fast, and reliable diagnostic tools is essential for the effective control of the disease. Therefore, this research optimized and compared IF and IHC techniques as alternative methods for definitive diagnosis of $L$. monocytogenes in FFPE tissues.

\section{MATERIALS AND METHODS}

\section{Sample selection}

Thirty FFPE tissues were selected from 15 animals with a history and/or histopathological lesions suggestive of Listeria sp. infection. These animals were submitted to necropsy or microscopic evaluation at the Veterinary Pathology laboratory of the Instituto Federal Catarinense, Campus Concórdia SC, from January 2013 to December 2019. Eight samples were from ruminants naturally infected with Listeria sp., including sheep ( $5 / 8$ cases), bovines ( $2 / 8$ cases) and a goat. These animals presented histopathological lesions in at least one fragment of the central nervous system (cerebrum, ceberellum, brainstem and/or spinal cord), which were characterized by multiple microabscesses, mononuclear perivascular cuffing, and sometimes, associated with malacia and Gitter cells.

Other 22 tissue samples were obtained from five cattle $(n=20)$ and two gerbils $(n=2)$ experimentally infected with L. monocytogenes ATCC 7644 (JAGUEZESKI et al., 2018; JAGUEZESKI et al., 2020). Gerbils were infected with $5 \times 10^{8} \mathrm{CFU}$ of bacteria per animal by the oral route and were euthanized at 12 days post infection (dpi), which were observed multifocal hepatic microgranulomas (JAGUEZESKI et al., 2020). Cattle were infected with $1.32 \times 10^{10} \mathrm{CFU}$ of bacteria per animal by the oral mucosa after scarification and were euthanized at 14 dpi (JAGUEZESKI et al., 2018). Fragments of liver, jejunum, oral mucosa, brainsteam and/or cerebrum from these animals were previously tested by qPCR (JAGUEZESKI et al., 2018; JAGUEZESKI et al., 2020) and only positive samples were selected for this study. Additionally, fragments of liver, jejunum, brain steam and cerebrum from uninfected bovines (control group) were used a negative control.

Microscopic lesions in each tissue were previously evaluated in Hematoxylin and Eosin (HE)stained slides, demarcated their spatial localization, and scored, according to the severity of inflammation $(0=$ absent, $1=$ mild inflammation, $2=$ moderate inflammation with multiple microabscess, 3 = severe inflammation with intralesional necrosis).

\section{Immunohistochemistry for L. monocytogenes}

IHC was performed as previously described by ROCHA et al. (2017), with modifications. Protocol variations were previously tested, including: with or without proteinase $\mathrm{K}$ (DAKO, USA) antigen retrieval; primary antibody dilution (1:100 or 1:200) and incubation period (45 or $90 \mathrm{~min}$ ); secondary antibody commercial kits with streptavidinperoxidase (LSAB, DAKO, USA) or with HRPpolymer conjugate (DAKO, USA); PBS-Tween washing period (5 or $15 \mathrm{~min}$ ); and chromogen kits of 3-amino-9-ethylcarbazole (AEC, DAKO, USA) or diaminobenzidine (DAB, DAKO, USA). The protocol with the best immunolabeling of positive controls, less nonspecific reaction, and the shortest incubation time was selected and described as follows.

Positively charged slides containing 3 $\mu \mathrm{m}$-thick histological tissues were heated at $56{ }^{\circ} \mathrm{C}$, 
incubated in xylene for complete paraffin removal, followed by hydration in a decreasing series of alcohol (100 to $70 \%)$ and washing in PBS solution with $0.05 \%$ Tween 20 (Dinâmica, Brazil) for 5 min. To avoid nonspecific reactions, samples were incubated with a $4 \%$ hydrogen peroxide solution for 45 min and washed, followed by incubation with skim milk (1:10 dilution in PBS) as a blocking solution, for $45 \mathrm{~min}$ at $37^{\circ} \mathrm{C}$ in a humid chamber. Then, after removing the blocking solution, the slides were incubated with a diluted $(1: 200)$ polyclonal anti- $L$. monocytogenes antibody (Listeria O Antiserum Poly Serotypes 1 and 4, Difco, USA) for $90 \mathrm{~min}$ in a humid chamber at $37^{\circ} \mathrm{C}$, washed with PBS-Tween and incubated for $30 \mathrm{~min}$ with a HRP-polymer conjugate secondary antibody (EnVision+Dual Link SystemHRP Polymer Kit, DAKO, USA). The reaction was revealed using 3-Amino-9-ethylcarbazole (AEC, DAKO, USA) and sections were counter-stained with Harris Hematoxylin. Slide reading was performed under an optical microscope and immunolabeling was evaluated and scored in each tissue sample, according to the percentage of positive area: negative $=<1 \%$ of positive area; $+=$ mild $(1-5 \%$ of positive area) $;++=$ moderate $(6-20 \%$ of positive area $) ;+++=$ severe ( $>20 \%$ of positive area). As negative controls, tissue samples from uninfected animals incubated with primary antibody were used, as well as positive tissues incubated with PBS-Tween solution.

\section{Immunofluorescence for L. monocytogenes}

For IF in FFPE tissues, the technique described by HENKE et al. (2015) was carried out with modifications. Protocol variations were previously tested, including: with or without proteinase $\mathrm{K}$ (DAKO, USA) antigen retrieval; serum dilution (2.5 or $10 \%)$ for blocking nonspecific binding sites; secondary antibody dilution (1:100 or 1:500), incubation period $(60,75$ or $105 \mathrm{~min})$ and incubation temperature (room temperature or $37{ }^{\circ} \mathrm{C}$ ); and Tween 20 concentration $(0.05$ or $0.1 \%)$ in PBS solution. The protocol with the best immunolabeling of positive controls, less nonspecific reaction, and the shortest incubation time was selected and described as follows.

Positively charged slides containing 3 $\mu \mathrm{m}$-thick histological tissues were heated at $56{ }^{\circ} \mathrm{C}$, incubated in xylol for complete paraffin removal, and hydrated in a decreasing series of alcohol (100 to $70 \%$ ) and PBS with $0.05 \%$ of Tween 20 (Dinâmica, Brazil) for $5 \mathrm{~min}$. To prevent nonspecific reactions, sections were incubated with equine serum (Vector, USA) diluted at $2.5 \%$ at $37{ }^{\circ} \mathrm{C}$ for $30 \mathrm{~min}$ in a humid chamber. After washing with PBS-Tween $0.05 \%$, the slides were incubated for $90 \mathrm{~min}$ at $37^{\circ} \mathrm{C}$, with the same primary antibody as described for IHC, i.e., diluted (1:200) polyclonal anti-L. monocytogenes antibody (Difco, USA). Then, the samples were washed and incubated with diluted (1:100) FITClabeled rabbit anti-IgG antibody (ab6717, Abcam, USA), for $105 \mathrm{~min}$ in a dark humid chamber at room temperature. Finally, all sections were washed in PBS-Tween and distilled water, mounted with glycerol (Isofar, Brazil) and analyzed up to 48 hours in a fluorescence microscope (Oxion ${ }^{\circledR}$ Euromex, Netherlands), with excitation filter $475 \mathrm{~nm} / \mathrm{AF} 40$ and emission filter $535 \mathrm{~nm} / \mathrm{AF} 45$. For image acquisition, a fluorescence microscope (Axio Observer Z1, Zeiss, Germany) with 100X immersion lens was used.

Each tissue was scored based on the presence and percentage of positive area of FITC immunolabeling: negative $=<1 \%$ of positive area; $+=$ mild ( $1-5 \%$ of positive area); $++=$ moderate $(6-20 \%$ of positive area); $+++=$ severe ( $>20 \%$ of positive area). Sequential sections of the same tissue block were used to compared IF score to the IHC result. As negative controls, tissue samples from uninfected animals incubated with primary antibody were used, as well as positive tissues incubated with PBS-Tween solution.

\section{Statistical analysis}

Sensitivity of IHC and IF were calculated separately in two animal groups: naturally infected and experimentally infected. As gold standard tests, qPCR of frozen tissues was used for experimentally infected animals (JAGUEZESKI et al., 2018; JAGUEZESKI et al., 2020), whereas histopathological lesion of neurologic listeriosis was used for naturally infected animals.

\section{RESULTS AND DISCUSSION}

Of the 30 tissues of selected animals, 10 samples $(33.3 \% ; 10 / 30)$ were positive in at least one of the techniques and of these, eight samples $(80 \% ; 8 / 10)$ were positive in both IHC and IF. Of all tissue fragments tested, only two bovine samples $(6.7 \% ; 2 / 30)$ showed a different result between the techniques, which a liver sample had mild immunostaining in IHC and was negative in IF, and a jejunum sample with mild immunostaining in IF and negative result in IHC.

There was strong immunolabeling by IHC (Figure 1A) and by IF (Figure 1B) in bovine tissues experimentally infected with $L$. monocytogenes ATCC 7644 , as well as in nervous tissues of ruminants with natural infection (Figures 1C and 1D). There was also 


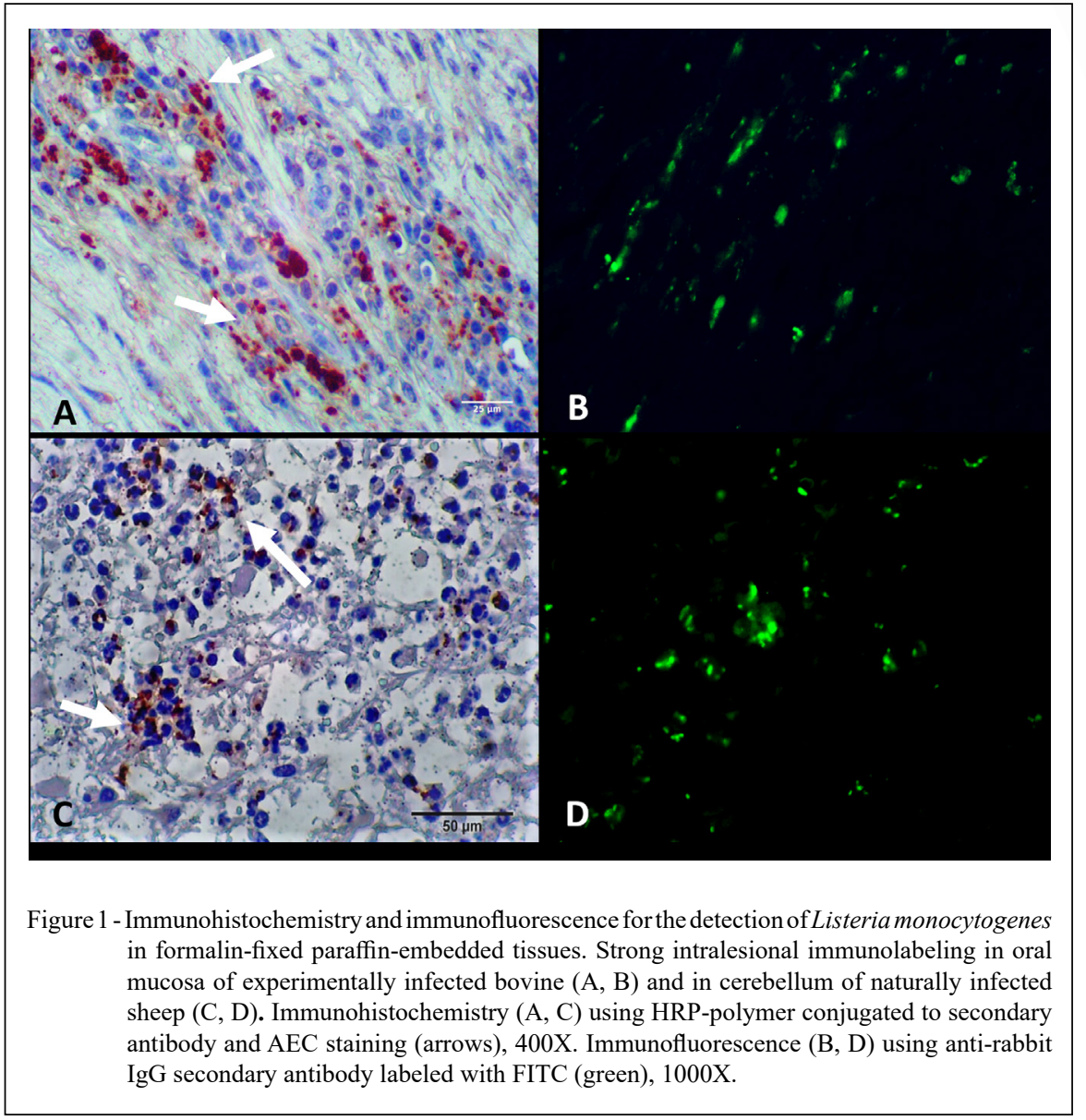

mild immunolabeling of liver from experimentally infected gerbils at 12 days post infection (dpi), as well as mild immunolabeling of the intestine and liver from experimentally infected bovines at 14 dpi. All samples from uninfected animals (control group) were negative in both techniques. The comparison of the results between IHC and IF is shown in table 1.

Interestingly, there was a variation in IHC and IF percentage of labeling area among different organs and animals; however, in all positive tissues, similar scores were observed between the two techniques. Additionally, no difference was observed in the sensitivity between IHC and IF for Listeria sp. detection. Sensitivity was $50 \%$ and $22.7 \%$ for naturally infected and experimentally infected animal groups, respectively.

In our study, the optimized IHC protocol using a polymer detection method conjugated to HRP reduced both incubation time and non-specific binding sites in FFPE tissues, when compared to the use of biotin-avidin or streptavidin-peroxidase kits (JOHNSON et al., 1995; RISSI et al., 2006; ROCHA et al., 2017; PRADO et al., 2019). The importance of this immunological technique compared to other diagnostic tools is given by the possibility of in situ and intralesional detection of the antigen, which may also enhance investigations of L. monocytogenes pathogenesis (RAMOS-VARA \& MILLER, 2014).

As in our research, other authors describe the efficiency of IHC to detect L. monocytogenes in animal tissues. In sheep, neurological listeriosis was confirmed through the IHC test in Rio Grande do Sul and Paraná, in which the pathogen was detected in the cytoplasm of neutrophils and macrophages (RISSI et al., 2010). The same was observed in our study, which showed strong immunolabeling of L. monocytogenes in neutrophil cytoplasm within cerebellar microabscesses in sheep (Figure $1 \mathrm{C}$ ). In goats, RISSI et al. (2006) confirmed neurological listeriosis in the central region of Rio Grande do Sul by the IHC method. This technique was also used

Ciência Rural, v.52, n.3, 2022. 
Table 1 - Comparison of immunohistochemistry (IHC) and immunofluorescence (IF) for Listeria monocytogenes detection in formalinfixed paraffin-embedded tissues.

\begin{tabular}{|c|c|c|c|}
\hline Samples (species, age, organ) & $\begin{array}{l}\text { Microscopic } \\
\text { lesion score }\end{array}$ & $\mathrm{IHC}$ & IF \\
\hline \multicolumn{4}{|l|}{ Natural infection } \\
\hline Sheep, 1 year old, brainstem & 3 & Negative & Negative \\
\hline Sheep, 1 year old, cerebrum & 2 & Negative & Negative \\
\hline Sheep, 1 year old, spinal cord & 2 & +++ & +++ \\
\hline Sheep, NI, cerebellum & 2 & +++ & +++ \\
\hline Sheep, 3 years old, brainstem & 2 & +++ & +++ \\
\hline Bovine, 20 months, brainstem & 2 & Negative & Negative \\
\hline Bovine, aborted fetus, cerebrum & 3 & Negative & Negative \\
\hline Goat, NI, brainstem & 3 & + & + \\
\hline \multicolumn{4}{|l|}{ Experimental infection * } \\
\hline Bovine, 6 months, oral mucosa & 3 & +++ & +++ \\
\hline Bovine, 6 months, oral mucosa & 2 & ++ & ++ \\
\hline Bovine, 26 months, pons, cerebrum, and liver & 0 & Negative & Negative \\
\hline Bovine, 13 months, pons, cerebrum, and liver & 0 & Negative & Negative \\
\hline Bovine, 12 months, pons, cerebrum, and liver & 0 & Negative & Negative \\
\hline Bovine, 6 months, pons, cerebrum, and jejunum & 0 & Negative & Negative \\
\hline Bovine, 6 months, pons, cerebrum, and liver & 0 & Negative & Negative \\
\hline Bovine, 6 months, liver & 0 & + & Negative \\
\hline Bovine, 12 months, jejunum & 1 & Negative & + \\
\hline Bovine, 6 months, jejunum & 1 & Negative & Negative \\
\hline Gerbil, 6 months, liver & 1 & + & + \\
\hline Gerbil, 6 months, liver & 1 & + & + \\
\hline
\end{tabular}

*Necropsy at 14 days post infection (dpi) in bovines and 12 dpi in gerbils. $\mathrm{NI}=$ not informed.

to detect L. monocytogenes antigens in nervous tissue of buffaloes (PRADO et al., 2019) and to confirm encephalic listeriosis in $83 \%$ of bovine cases with successful bacterial isolation (JOHNSON et al., 1995).

The performance of IF in FFPE tissues, instead of fresh ones, may be considered quite unique, since there are few studies describing this technique for laboratory diagnosis of listeriosis in processed biological materials. HENKE et al. (2015) analyzed 11 brain tissue sections of small ruminants by IF and obtained a positive result in all samples, with the vast majority of bacterial antigen found within brain microabscesses.

With the adjusted IF protocol used in this research, as well as the IHC protocol, L. monocytogenes immunolabeling was not compromised with the removal of the antigen retrieval step. In addition, the shorter incubation time with a new primary antibody has optimized the technique to obtain a faster result, when compared to the previously described IF methodology for FFPE tissues (HENKE et al., 2015). Moreover, when comparing the described protocols for IF and IHC, the latter was, in our condition, a less expensive technique and easier to interpret the results.

In the IHC and IF techniques, only two samples showed different results. Despite using sequential cuts of the same tissue blocks to compare both techniques, variable amount of detectable antigen may have occurred among the analyzed tissue fragments. Additionally, a valid comparation between IF and IHC results were assessed due to minimal variation of both protocols until secondary antibody incubation, such as: (i) endogenous peroxidase inactivation in IHC, as the reaction is revealed with HRP enzymatic activity conjugated to the secondary antibody; and (ii) serum blocking solution instead of skim milk in IF, to avoid autofluorescent components.

Therefore, this study demonstrated that the two immunological techniques were efficient in detecting L. monocytogenes in FFPE tissues, with consistent localization of antigen immunolabeling in the same tissue sections. Although IF did not show any difference in sensitivity when compared with 
IHC, this technique has a potential role in diagnostic laboratories, as well as in situ studies of host-pathogen interactions during animal listeriosis.

\section{CONCLUSION}

Immunohistochemistry (IHC) and immunofluorescence (IF) techniques were effective for L. monocytogenes detection in FFPE tissues of naturally and experimentally infected animals. Even though no difference in sensitivity was observed between the evaluated techniques, IF showed its potential application as diagnostic tool and for further studies related to Listeria sp. pathogenesis in FFPE animal tissues.

\section{ACKNOWLEDGEMENTS}

This research was financed by the Conselho Nacional de Desenvolvimento Científico e Tecnológico (CNPq) (Project no. 431214/2016-16), IFC, and in part by the Coordenação de Aperfeiçoamento de Pessoal de Nível Superior (CAPES), Brasil - Finance code 001

\section{DECLARATION OF CONFLICT OF INTEREST}

The authors declare no conflict of interest.

\section{AUTHORS' CONTRIBUTIONS}

All authors contributed equally for the conception and writing of the manuscript. All authors critically revised the manuscript and approved the final version.

\section{REFERENCES}

BARKALLAH, M. et al. Locked nucleic acid probe-based real-time PCR for the diagnosis of Listeria monocytogenes in ruminants. Molecular and Cellular Probes, v.30, n.3, p.138-145, 2016. Available from: <https://doi.org/10.1016/j. mcp.2016.02.010>. Accessed: Jul. 12, 2020. doi: 10.1016/j. mcp.2016.02.010.

HENKE, D. et al. Listeria monocytogenes spreads within the brain by actin-based intra-axonal migration. Infection and Immunity, v.83, n.6, p.2409-2419, 2015. Available from: <https://iai.asm. org/content/iai/83/6/2409.full.pdf $>$. Accessed: Sep. 29, 2018. doi: 10.1128/IAI.00316-15.

JAGUEZESKI, A. M. et al. Listeria monocytogenes impairs enzymes of the phosphotransfer network and alters antioxidant/ oxidant status in cattle brain structures. Microbial Pathogenesis, v.124, p.284-290, 2018. Available from: $<$ https://doi.org/10.1016/j. micpath.2018.08.044>. Accessed: Mar. 20, 2019. doi: 10.1016/j. micpath.2018.08.044.

JAGUEZESKI, A. M. et al. Changes in cardiac and hepatic energetic metabolism in gerbils infected by Listeria monocytogenes.
Microbial Pathogenesis, v.138, p.103786, 2020. Available from: $<$ https://doi.org/10.1016/j.micpath.2019.103786>. Accessed: Jun. 03, 2020. doi: 10.1016/j.micpath.2019.103786.

JOHNSON, G. C. et al. Evaluation of laboratory tests for confirming the diagnosis of encephalitic listeriosis in ruminants. Journal of Veterinary Diagnostic Investigation, v.7, n.2, p.223228, 1995. Available from: <https://journals.sagepub.com/doi/abs /10.1177/104063879500700210>. Accessed: Aug. 03, 2018. doi: $10.1177 / 104063879500700210$.

KIRINUS, J. K. et al. Outbreak of systemic listeriosis in chinchillas. Ciência Rural, v.40, n.3, p.686-689, 2010. Available from: <https://www.scielo.br/scielo.php?pid=S0103$84782010000300033 \&$ script $=$ sci_arttext $>$. Accessed: Sep. 06, 2020. doi: 10.1590/S0103-84782010000300033.

LIU, D. Molecular approaches to the identification of pathogenic and nonpathogenic listeriae. Microbiology Insights, v.6, S10880, 2013. Available from: <https://journals.sagepub.com/ doi/full/10.4137/MBI.S10880>. Accessed: Oct. 10, 2019. doi: 10.4137/MBI.S10880.

LOEB, E. Encephalitic listeriosis in ruminants: Immunohistochemistry as a diagnostic tool. Journal of Veterinary Medicine Series A, v.51, n.9-10, p.453-455, 2004. Available from: <https://onlinelibrary.wiley.com/doi/abs/10.11 11/j.1439-0442.2004.00656.x>. Accessed: Aug. 12, 2020. doi: 10.1111/j.1439-0442.2004.00656.x.

LOPES, L. B. Listeriose: encefalites nos animais domésticos. PUBVET, v.4, p.752-758, 2010. Available from: <http://www. pubvet.com.br/artigo/1828/listeriose-encefalites-nos-animaisdomeacutesticos>. Accessed: Sep. 22, 2019.

LOW, J. C.; DONACHIE, W. A review of Listeria monocytogenes and listeriosis. The Veterinary Journal, v.153, n.1, p.9-29, 1997. Available from: <https://doi.org/10.1016/S1090-0233(97)80005-6>. Accessed: Jan. 10, 2019. doi: 10.1016/S1090-0233(97)80005-6.

OEVERMANN, A. et al. Rhombencephalitis caused by Listeria monocytogenes in humans and ruminants: a zoonosis on the rise? Interdisciplinary Perspectives on Infectious Diseases, v.2010, 2010. Available from: <https://www.hindawi.com/ journals/ipid/2010/632513/>. Accessed: Jan. 10, 2019. doi: $10.1155 / 2010 / 632513$.

PRADO, R. G. S. et al. Nervous form of listeriosis in buffaloes. Pesquisa Veterinária Brasileira, v.39, n.5, p.299-303, 2019. Available from: <https:/www.scielo.br/scielo.php?pid=S0100736X2019000500299\&script=sci_arttext/>. Accessed: Apr. 11, 2020. doi: 10.1590/1678-5150-pvb-6038.

RAMOS-VARA, J. A.; MILLER, M. A. When tissue antigens and antibodies get along: revisiting the technical aspects of immunohistochemistry-the red, brown, and blue technique. Veterinary Pathology, v.51, n.1, p.42-87, 2014. Available from: <https://journals.sagepub.com/doi/ full/10.1177/0300985813505879>. Accessed: May, 03, 2019. doi: $10.1177 / 0300985813505879$.

RISSI, D. R. et al. Listeric meningoencephalitis in goats. Pesquisa Veterinária Brasileira, v.26, n.1, p.14-20, 2006. Available from: <https://www.scielo.br/scielo.php?pid=S0100736 X2006000100004\&script $=$ sci_arttext $>$. Accessed: Mar. 22, 2019. doi: 10.1590/S0100-736X2006000100004. 
RISSI, D. R. et al. Meningoencephalitis in sheep caused by Listeria monocytogenes. Pesquisa Veterinária Brasileira, v.30, n.1, p.51-56, 2010. Available from: <https://www.scielo. $\mathrm{br} / \mathrm{scielo} . \mathrm{php}$ ?pid $=\mathrm{S} 0100-736 \mathrm{X} 2010000100008 \& \mathrm{script}=\mathrm{sci}$ arttext>. Accessed: Mar. 22, 2019. doi: 10.1590/S0100$736 \times 2010000100008$.

ROCHA, C. E. et al. Comparative experimental infection of Listeria monocytogenes and Listeria ivanovii in bovine trophoblasts. PloS
One, v.12, n.5, 2017. Available from: <https://journals.plos.org/ plosone/article?id=10.1371/journal.pone.0176911>. Accessed: Aug. 02, 2018. doi: 10.1371/journal.pone.0176911.

SWAMINATHAN, B.; GERNER-SMIDT, P. The epidemiology of human listeriosis. Microbes and Infection, v.9, n.10, p.1236-1243, 2007. Available from: <https://doi.org/10.1016/j. micinf.2007.05.011>. Accessed: Oct. 02, 2019. doi: 10.1016/j. micinf.2007.05.011. 